\title{
Global Climate Change and Emerging Environmental and Strategic Security Issues for South Asia
}

\author{
Amarendra Nath Sarkar \\ Asia Pacific Institute of Management, Institutional Area, Jasola Vihar, New Delhi, India. \\ Email: ansarkar@asiapacific.edu
}

Received July $12^{\text {th }}, 2011$; revised September $8^{\text {th }}, 2011$; accepted October $16^{\text {th }}, 2011$.

\begin{abstract}
Global climate change-essentially an adverse consequence of global warming, is principally caused by progressive build-up and extensive spread of greenhouse gases (GHGs) across countries, regions or continents because of earth's rotational movement. The potent sources of GHGs are fossil-fuels and biomass. With the increasing pace of globalization, industrialization and rapid change of life-style the demand and consumption of these feed-stocks to stimulate economic growth is steadily rising- both in the developing and developed economy. In the process, the emissions level is also rising phenomenally; and of late become quite alarming - more in the former than latter case, affecting thereby the environmental quality as also its security concerns globally. This paper highlights the major impacts of global warming and consequential climate change on the environmental quality and overall security aspects- including commercial, strategic and defense angles for the South-Asian region. The paper also discusses some relevant aspects linking the larger question of energy security with environmental security through the approach of sustainable energy development for envisioning a balanced economic development as well as growth perspective for South Asia. The significance of International cooperation in the mitigation and adaptation of climate change impacts with special reference to AsiaPacific and South Asian region is also discussed at some length in the paper.
\end{abstract}

Keywords: Global Climate, Environmental Security, South Asia, Sustainable Energy Development, Mitigation and Adaptation, International Cooperation

\section{Global Warming and Climate Change}

The terms global warming and climate change are often used co-tremendously, but the two phenomena are different. Global warming is the rise in global temperatures due to an increase of heat-trapping carbon emissions in the atmosphere. Climate change, on the other hand, is a more general term that refers to changes in many climatic factors (viz. temperature and precipitation) around the world. These changes are happening at different rates and in different ways. The world mostly agrees that something needs to be done about global warming and climate change. The first stumbling block, however, has been trying to get an agreement on a unanimous framework. In 1988, the Intergovernmental Panel on Climate Change was created by the United Nations Environment Programme and the World Meteorological Organization to assess the scientific knowledge on global warming. The IPCC concluded in 1990 that there was broad interna- tional consensus that climate change was human-induced. That report led the way to an international convention for climate change-namely the United Nations Framework Convention on Climate Change (UNFCCC), signed by over 150 countries at the Rio Earth Summit in 92 [1].

Intergovernmental Panel on Climate Change reported that greenhouse gas (GHG) concentrations in the global atmosphere were rising as a result of human ghg emissions, principally from fossil fuel burning. This is clearly a 'global problem'. There is yet another dimension to the global problem. While the global dependency on fossil energy for economic growth remains nearly $100 \%$ at this time, the IPCC also noted that cuts in GHG emissions in the order of $60 \%-80 \%$ were required immediately if rising atmospheric GHG concentrations were to be stabilized just at the present raised values [2].

\section{Impact and Risks of Global Warming}

As the earth's surface absorbs the sun's rays, the heat 
bounces back, and a part of it ultimately escapes into space. On its way through the atmosphere the heat is absorbed by carbon dioxide and methane molecules; this process raises the temperature on the earth's surface. The more carbon dioxide there is in the atmosphere, the more heat is entrapped. This phenomenon is called the "greenhouse effect". The 'greenhouse effect' is the process in which the emission of infrared radiation by the atmosphere warms a planet's surface [3]. World's carbon dioxide emissions are expected to increase by 1.9 percent annually between 2001 and 2025. Much of the increase in these emissions is expected to occur in the developing world where emerging economies, such as China and India, fuel economic development with fossil energy. Developing countries' emissions are expected to grow above the world average at 2.7 percent annually between 2001 and 2025; and surpass emissions of industrialized countries near 2018 [4].

The major impacts of global climate changes are manifested in gradual rise in global surface temperature (i.e. global warming), melting of ice-bergs and concomitant rise in sea-levels, continuous build-up of greenhouse gases leading to 'green-house effect', depletion of ozone concentration/layers, catastrophic natural disaster and calamities (e.g. hurricane, typhoons, earthquakes, landslides, Tsunami), loss of vegetation, plant, animal lives, biodiversities, marine flora \& fauna etc. The widespread retreat of glaciers and icecaps in the 21st century will also lead to higher surface temperatures on land and increasing water stress [5]. By 2025, as much as two-thirds of the world population, much of it in the developing world, may be subjected to moderate to high water stress. Estimates of the effects of climate change on crop yields are predominantly negative for the tropics, even when adaptation and direct effects of $\mathrm{CO}_{2}$ on plant processes are taken into consideration. Ecological productivity and biodiversity will be altered by climate change and sealevel rise, with an increased risk of extinction of some vulnerable species. In the final analysis, scientists will continue to study the critical and important issues of the effects of adverse air quality and climate change on crop production as also the larger question of global food security $[6,7]$. Industrialized countries are largely responsible for the build-up of GHGs in the atmosphere thus far, and must bear the brunt of the mitigation effort. But deve- loping countries can play an important role in reducing emissions growth within the context of their continued economic development. Nearly 80 percent of the world's population lives in developing countries, which already account for over 40 percent of current world emissions and given present trends, this share will rise to 56 percent by 2025 [8].

The impacts on human systems of climate change will probably be distributed unevenly. Some regions and sectors are expected to experience benefits while others will experience costs. With greater levels of warming (greater than $2^{\circ} \mathrm{C}-3^{\circ} \mathrm{C}$, relative to 1990 levels), it is likely that benefits will decline and costs increase. Low-latitude and less-developed areas are probably at the greatest risk from climate change. With human systems, adaptation potential for climate change impacts is considerable, although the costs of adaptation are largely unknown and potentially large. Climate change will likely result in reduced diversity of ecosystems and the extinction of many species. Adaptation potential for biological and geophysical systems is estimated to be lower than that for human systems.

\subsection{Concern over Glacier Retreat, Rise of Sea Levels and Temperature}

According to a UN climate report, the Himalayan glaciers that are the sources of Asia's biggest riversGanges, Indus, Brahmaputra, Yangtze, Mekong, Salween and Yellow-could disappear by 2035 as temperatures rise. Approximately, 2.4 billion people live in the drainage basin of the Himalayan rivers. India, China, Pakistan, Bangladesh, Nepal and Myanmar could experience floods followed by droughts in coming decades. In India alone, the Ganges provides water for drinking and farming for more than 500 million people. It has to be acknowledged, however, that increased seasonal runoff of Himalayan glaciers led to increased agricultural production in northern India throughout the 20th century. The role of the oceans in global warming is a complex one. The oceans serve as a sink for carbon dioxide, taking up much that would otherwise remain in the atmosphere, but increased levels of $\mathrm{CO}_{2}$ have led to ocean acidification. Furthermore, as the temperature of the oceans increases, they become less capable to absorb excess $\mathrm{CO}_{2}$. Global warming is projected to have a number of effects on the oceans. Ongoing effects include rising sea levels due to thermal expansion and melting of glaciers and ice sheets, and warming of the ocean surface, leading to increased temperature stratification. The temperature of the Antarctic Southern Ocean rose by $0.17^{\circ} \mathrm{C}\left(0.31^{\circ} \mathrm{F}\right)$ between the 1950s and the 1980s, nearly twice the rate for the world's oceans as a whole.

\subsection{Effects on Agriculture and Food Security}

Climate change is expected to have a mixed effect on agriculture, with some regions benefiting from moderate temperature increases and others being negatively affected. Low-latitude areas are at most risk of suffering decreased crop yields. Mid- and high-latitude areas could see increased yields for temperature increases of up to $1^{\circ} \mathrm{C}-3^{\circ} \mathrm{C}$ (relative to the period $\left.1980-1999\right)$. According 
to the IPCC report above $3^{\circ} \mathrm{C}$ of warming, global agricultural production might decline, but this statement is made with low to medium confidence [2]. Most of the agricultural studies assessed in the Report do not include changes in extreme weather events, changes in the spread of pests and diseases, or potential developments that may aid adaptation to climate change. Increasing global temperature means that ecosystems will change; some species are being forced out of their habitats because of changing conditions, while others are flourishing. Secondary effects of global warming, such as lessened snow cover, rising sea levels, and weather changes, may influence not only human activities but also the ecosystem. The continued retreat of glaciers will have a number of different effects. In areas that are heavily dependent on water runoff from glaciers that melt during the warmer summer months, a continuation of the current retreat will eventually deplete the glacial ice and substantially reduce or eliminate runoff. This situation is particularly acute for irrigation in South America, where numerous artificial lakes are filled almost exclusively by glacial melt. Central and South Asian countries have also been historically dependent on the seasonal glacier melt water for irrigation and drinking supplies.

According to some recent study it is projected that by 2025, two thirds of the world's people are likely to live in countries with water shortages [9]. Remaining fossil fuel reserves are increasingly concentrated in relatively few countries-not usually those with the greatest demand. Food production per person has leveled off, and stocks are falling. The most vulnerable groups in terms of food security during floods in south Asia under climate change will be the poor, women and children. Current procedures for the transfer of climate adaptation funds tend to marginalize these groups. Food production is being disrupted by flooding more frequently and more severely than before, due to climate change. By 2080 the situation is likely to be much worse than at present. Adaptation has to encourage management of all stages of food security, from the farm to the consumer, both urban and rural. Measures have to be participatory, from the community to the international level ${ }^{8}$. While many individual initiatives offer hope and demonstrate good practice, institutional, economic and environmental factors may all impede the maintenance and enhancement of food security in south Asia. Innovative forms of food production, distribution and storage will have to be developed. The Asian region spans polar, temperate, and tropical climates and is home to over 3 billion people. As the climate warms, many mountain glaciers may disappear, permafrost will thaw, and the northern forests are likely to shift further north. Rapid population growth and development in countries like China and India will put additional pressures on natural ecosystems and will lead to a rapid rise in the release of greenhouse gases into the atmosphere unless steps are taken to curtail emissions [10].

\section{Global Warming and Adverse Environmental \& Economic Impacts in South Asia}

The impact of global warming is visible in communities throughout the world as demonstrated most recently and dramatically in North America and Europe, where unexpected heat waves and storms caused by the shifting climate decimated crops and inflicted serious financial losses on farmers. Inhabitants of low lying islands, such as Tuvalu, the Maldives and the Solomon Islands, are finding their drinking water adulterated by rising seas that also threaten to obliterate parts of their national territories. Even more catastrophic is the rapid shrinking of mountain glaciers that feed lakes and rivers; the ultimate outcome is the drying up of vital melt-water sources for irrigation, hydroelectric schemes and drinking. The retreat of glaciers in the Andes is already plummeting water supplies in Ecuador, Peru, and Bolivia. People in the South Asian part of Himalayas are not exempt: Melting glaciers in the world's highest mountain range are swelling local lakes, triggering flash-flooding in the narrow valleys below. In 1994, a glacier-lake outburst in the Lunana region of Bhutan flooded a number of villages, endangering the lives of thousands of people. The burst of the Dudh Koshi Lake in Nepal in 1997 had similar repercussions. This trend, experts argue, will accelerate in the next half decade, creating social and economic problems not only for the villages in the Himalayan foothills but also for the entire South Asian region [11]. South- east Asia is one of the world's most vulnerable regions to climate change and could face conflict over failing rice yields, lack of water and high economic costs, a major Asian Development Bank report shows.

The region's economies could lose as much as 6.7 percent of combined gross domestic product yearly by 2100 , more than twice the global average loss, according to the ADB's report on the economics of climate change in Southeast Asia [12]. The global economic downturn could delay funding for climate change mitigation measures by regional governments. According to the findings of ADB study, if nothing was done globally to fight climate change, Southeast Asia could suffer a decline in rice output potential of about 50 percent on average by 2100 against 1990 levels. These schemes could involve the shift to renewable and clean energy options for the power and transport sectors across Southeast Asia, home to nearly 600 million people. UNEP scientists have surveyed more than 4000 glaciers in Nepal and Bhutan and 
concluded that 20 glacial lakes in the Bhutanese Himalayas and 24 glacial lakes in Nepal pose a potential hazard. They warn that a number of lakes are still unexplored, especially in India (where most of the Himalayas lie), Pakistan, and Afghanistan. In order to make a comprehensive report, UNEP-ICIMOD's (United Nations Environment Programme - International Centre for Integrated Mountain Development) study will expand to all South Asian countries, including China, as well neighboring countries in central Asia.

\section{Environment, Development and Human Security: Perspectives from South Asia}

According to Najam [13]—a Research scholar of Tufts University, South Asia is the world's most impoverished region, with the highest rate of illiteracy and over 500 million people living below the absolute poverty line. Given this context, Najam argued that it is erroneous to think of security primarily as a matter of states and their military alliances and to define security as the safety of borders and institutions from outside threats. Rather, the true sources of insecurity in South Asia are non-military threats arising within the nations-such as poverty, social vulnerability, and ecological resiliency. He explained that in Bangladesh, "poverty is, and will remain the most important source of vulnerability and insecurity.” As a result, Najam advocated that academics and policy-makers eschew the traditional conception of security and instead focus on human security and institutional failure. According to Najam poverty plays a more central role than has been acknowledged in linking environmental degradation and conflict. In Nepal, for example, "environmental stresses interact with societal vulnerability, disrupted development, and perverse markets to create an atmosphere of insecurity." Thus, he stated that chronic and structural poverty may be a required condition for the connection between the environment and security to be made. He also suggested that good governance is critical to ensuring resource availability and sustainable development. Based on these insights, Najam made some general conclusions and recommendations. First, for developing countries, especially in South Asia, it is best to conceptualize environment and security within the context of sustainable development. Second, the challenges of environment and security in South Asia are primarily a problem of institutions and governance. Finally, there is a small potential for forging more cooperative relations in the region based on the nexus of environment and security. According to Burgess, Stephen [14] India has an emerging security strategy influenced by the 1998 Indo-Pak nuclear tests, the National Security Advisory Board's Draft Nuclear Weapons Doctrine, the concept of limited conventional war, and endorsement of mi- ssile defense. India's defense capabilities lag behind the development of strategic thinking. However, India's partnership with United States has opened the door to further developments in security strategy and defense capabilities.

\section{Climate Change and Its Possible Impact on India and the Subcontinent}

India, the seventh largest country in the world and the second largest in Asia, has a total geographical area of 329 Mha, of which only 305 Mha is the reporting In developing countries like India, climate change could represent an additional stress on ecological and socioeconomic systems that are already facing tremendous pressures due to rapid urbanization, industrialization and economic development. With its huge and growing population, a 7500-km long densely populated and lowlying coastline, and an economy that is closely tied to its natural resource base, India is considerably vulnerable to the impacts of climate change. The various studies conducted in the country have shown that the surface air temperatures in India are going up at the rate of $0.4^{\circ} \mathrm{C}$ per hundred years, particularly during the post-monsoon and winter season [15]. India is heavily dependent on the monsoon to meet its agricultural and water needs, and also for protecting and propagating its rich biodiversity. Apart from monsoon rains, India uses perennial rivers, which originate and depend on glacial melt-water in the Hindukush and Himalayan ranges. Since the melting season coincides with the summer monsoon season, any intensification of the monsoon is likely to contribute to flood disasters in the Himalayan catchment. Rising temperatures will also contribute to the raising of snowline, reducing the capacity of this natural reservoir, and increasing the risk of flash floods during the wet season. Increased temperatures will impact agricultural production. A trend of sea level rise of $1 \mathrm{~cm}$ per decade has been recorded along the Indian coast. Sea level rise due to thermal expansion of sea water in the Indian Ocean is expected to be about $25-040 \mathrm{~cm}$ by 2050 [16]. This could inundate low lying areas, down coastal marshes and wetlands, erode beaches, exacerbate flooding and increase the salinity of rivers, bays and aquifers. Deltas will be threatened by flooding, erosion and salt intrusion. Loss of coastal mangroves will have an impact on fisheries. The major delta area of the Ganga, Brahmaputra and Indus rivers, which have large populations reliant on riverine resources will be affected by changes in water regimes, salt water intrusions and land loss. Increase in temperatures will result in shifts of lower altitude tropical and subtropical forests to higher altitude temperate forest regions, resulting in the extinction of some temperate vegetation types. Increased dry spells could also 
place dry and moist deciduous forests at increased risk from forest fires. Climate change will make monsoons unpredictable. As a result, rain-fed wheat cultivation in South Asia will suffer in a big way.

\section{Global Climate Change and Defense Strategic Implication}

The Military Advisory Board, a panel of retired U.S. generals and admirals released a report entitled "National Security and the Threat of Climate Change." The purpose of the Military Advisory Board's study was to examine the national security consequences of climate change. A dozen of the nation's most respected retired admirals and generals served as a Military Advisory Board to study how climate change could affect our nation's security over the next 30 to 40 years - the timeframe for developing new military capabilities [17]. The report predicts that global warming will have security implications, in particular serving as a "threat multiplier" in already volatile regions.

The major recommendations of the Military Advisory Board are:

- Projected climate change poses a serious threat to America's national security

- Climate change acts as a threat multiplier for instability in some of the most volatile regions of the world

- Climate change, national security, and energy dependence are a related set of global challenges

In November 2007, two Washington think tanks, the established Center for Strategic and International Studies and the newer Center for a New American Security, published a report analyzing the worldwide security implications of three different global warming scenarios. Climate change will pose profound strategic challenges to the United States in coming decades, raising the prospect of military intervention to deal with the effects of violent storms, drought, mass migration and pandemics, The New York Times reported [18]. Citing military and intelligence analysts, the newspaper said climate-induced crises could topple governments, feed terrorist movements or destabilize entire regions. Analysts, experts at the Pentagon and intelligence agencies for the first time are taking a serious look at the national security implications of climate change, the report said. Recent war games and intelligence studies conclude that over the next 20 to 30 years, vulnerable regions, particularly sub-Saharan Africa, the Middle East and South and Southeast Asia, will face the prospect of food shortages, water crises and catastrophic flooding driven by climate change that could demand an US humanitarian relief or military response. An exercise at the National Defense University last December explored the potential impact of a flood in Bangladesh that sent hundreds of thousands of refugees streaming into neighboring India, touching off religious conflict, the spread of contagious diseases and vast damage to infrastructure, according to The Times. A changing climate presents a range of challenges for the military, the paper pointed out, because many of its critical installations are vulnerable to rising seas and storm surges. Military planners are studying ways to protect the major naval stations in Norfolk, Virginia, and San Diego, California, from climate-induced rising seas and severe storms. Another vulnerable installation is Diego Garcia, an atoll in the Indian Ocean that serves as a logistics hub for US and British forces and sits a few feet above sea level.

According to a report published in IPS, Washington (by Jim Lobe) [19] on 5 November, 2008, Global climate change, if left unaddressed, is likely to pose "as a great or a greater foreign policy and national security challenge than any problem" the United States currently faces, according to a major new report released here Monday by two influential Washington think tanks. Under a worst-case scenario, that nonetheless remains "plausible" given the latest scientific estimates, climate change's impacts on global stability "would destabilize virtually every aspect of modern life," according to the conclusions of a task force assembled by the Centre for Strategic and International Studies and the Centre for a New American Security (CNAS). The second IPCC report coincided with the release of yet another study by a panel of retired senior U.S. military officers that warned, among other things, that sea-level rise and a dearth of fresh water-particularly in the Middle-East, Africa, and South and Southeast Asia—would "foster the conditions for internal conflicts, extremism and movement toward increased authoritarianism and radical ideologies.” The expected decline in food production and fresh drinking water, combined with greater possibilities for intra-state and inter-state conflict, will drive more Africans and South Asians to migrate further abroad, possibly resulting in a major surge in the number of immigrants to Europe, according to the report.

There is growing consensus that environmental degradation can, and does, trigger, amplify or cause conflict and instability, and a growing concern that environmentally induced conflict might increase. Today, security institutions are being called upon to protect access to environmental resources in other countries as well as in the global commons, and to provide support for humanitarian operations, many of which have significant environmental roots. In the future, force may be used in response to trans-boundary pollution, or to enforce international environmental law. But security specialists recognize that conflict can be a constructive force, signaling the need for institutional change or capacity building. The 
pressures placed on institutions by environmental degradation and resource scarcity might be just such a signal. Building sustainable peace between and within countries requires the international community to tackle the root causes of conflict. In terms of the environment, this includes managing our natural resources more effectively and halting environmental degradation. In this context, IISD's focus is to provide practical recommendations to decision-makers on how better environmental management could reduce the risk of conflict [20].

\section{Climate Security Index: A Measure of Global Climate Disruption}

Climate Security Index, a new report by the American Security Project, links global climate change impacts and energy insecurity to US national security, concluding that these interrelated problems constitute a "clear and present danger to the national security of the United States." The report says global climate change is projected to produce "insufficient water supplies, shifting rainfall patterns, disruptions to agriculture, human migrations, more failing states, increased extremism, and even resource wars," all of which pose an urgent threat that must be addressed in national security policy. The Index addresses, inter alia, what are the human security issues that must be addressed in the larger international policy context. The American Security Project is a non-profit, bipartisan public policy and research initiative to educate the American public about the changing nature of national security in the 21st century [21]. Their board of directors is composed of high-ranking retired military officers, public servants including current and former US Senators, and former government officials.

Climate Security Index represents a renewed effort to sound the alarm based on current, authoritative knowledge. The projected global impacts of climate change spell out a clear and present danger for the United States, says the report: "Climate change refugees will increasingly cross our own borders. In South Asia, the melting of Himalayan glaciers jeopardizes fresh water supplies for more than one billion human beings. The nonpartisan think tank American Security Project's Secure America Future program recently released a new report entitled Climate Security Index, detailing climate security threats around the globe. The report looks at the numerous impacts of climate change throughout the world, identifying key "hot spots" where impacts pose the greatest security concerns, such as Central America, Sub-Saharan Africa, and Southeast Asia. New climate conditions will drive human beings to move in ever larger numbers, seeking food, water, shelter and work. No region will be immune. Climate refugees will increasingly cross our own borders. The stress of changes in the environment will further weaken marginal states. Failing states will incubate extremism. In South Asia, the melting of Himalayan glaciers jeopardizes fresh water supplies for more than one billion human beings.

\section{UNFCCC Mandate to Mitigate Impact of Climate Change}

In 1988, the Intergovernmental Panel on Climate Change was created by the United Nations Environment Programme (UNEP) and the World Meteorological Organization (WMO) to assess the scientific knowledge on global warming. The IPCC concluded in 1990 that there was broad international consensus that climate change was human-induced. That report led way to an international convention for climate change, the United Nations Framework Convention on Climate Change (UNFCCC), signed by over 150 countries at the Rio Earth Summit in 1992 [22]. The various recommendations emanated from this Summit, inter alia, also led the way and made foundation for evolving the concept of sustainable development. One of the mandates of UPCCC is evolving mitigation measures to minimize the adverse impact of climate change [23]. Mitigation measures to reduce greenhouse gas emissions have a certain cost. However, they also constitute an economic benefit by reducing the impacts of climate change, and the costs associated with them. The resulting mitigation potential is substantial and could offset the projected growth of global emissions over the coming decades or reduce emissions below current levels [23].

Mitigation measures could contribute to stabilizing the concentration of greenhouse gases in the atmosphere by 2100 or later. To achieve low stabilization levels, stringent mitigation efforts are needed in the coming decades. This could reduce global GDP by up to a few percent. Changes in lifestyle and behaviour that favor resource conservation can contribute to climate change mitigation. Mitigation measures can also have other benefits for society, such as health cost savings resulting from reduced air pollution. However, mitigation in one or group of countries could lead to higher emissions elsewhere or effects on the global economy. Mitigation potential for different sectors is a function of carbon price) [24]. No one sector or technology can address the entire mitigation challenge. All sectors, including buildings, industry, energy production, agriculture, transport, forestry, and waste management could contribute to the overall mitigation efforts, for instance through greater energy efficiency. World-wide investments in mitigation technologies, as well as research into new energy sources, will be necessary to achieve stabilization. Delaying emission reduction measures limits the opportunities to achieve low stabilization levels and increases the risk of severe 
cli- mate change impacts [25,26].

\section{Climate Change and Addressing Food Security as a Measure of Mitigation}

These are the poorest regions in the world with high levels of chronic under-nourishment, and are the ones which contributed the least to the problem of environment decay and climate change. But they will be the hardest hit. The international community and the developed nations have expressed concern towards them in a recent G8 summit declaration which states," We underscore that climate change severely affects developing countries and is becoming a major threat to their ability to achieve internationally agreed development goals including the MDGs." The impacts of climate change on agriculture and food security are manifold. This scenario predicts regional disparities in food production and availability. Moreover, with an increase in climate variability, another dimension of climate change, the IPCC predicts that the world will face increased frequency and severity of cyclones, floods, storms and droughts, causing fluctuations in crop yields and local food supplies. These inconsistencies will have serious effects on semi-arid areas, like Sub-Saharan Africa and certain parts of South Asia [25, 26]. But there is a ray of hope.

The Food and Agriculture Organization (FAO) of the UN predicts that the overall global food production is likely to keep pace with population growth and the food demand in the future. Thus, apart from taking mitigating action to halt the climate change, the International Community faces the challenge of removing the regional disparities in the availability of food across the globe. Currently, the UN and the developed actions respond to food needs of populations in emergency situations after natural disasters or in conflict areas.

\section{Global Initiatives for Energy Security \& Sustainable Development}

Inter-country cooperation can play an important role in addressing issues related to energy supply and demand and the efficient distribution of energy resources through, among others, connectivity and trade. While improving energy security is primarily a domestic issue, trans-boundary energy cooperation could play an important complementary role. Currently, most Governments are individually seeking and taking measures to ensure a steady supply of energy resources to sustain their economic growth. In the era of globalization, a collective cooperation framework could supplement national efforts and bring mutual benefits. A cooperation framework could include a coordinated planning and development approach for trade and exchange, which could lead to the integration of energy infrastructure aimed at facilitating the supply of energy to final consumption destinations beyond national boundaries. It is heartening to note that platforms for cooperation have already been initiated in some sub regions, including South-East Asia, North-East Asia, South-Asia and West and Central Asia. Least developed and landlocked developing countries in these sub regions stand to benefit through active engagement in their respective regions. Moreover, another initiative for broad trans-Asian energy cooperation that ESCAP has been pursuing following the sixty-second session of the Commission could also benefit least developed and landlocked developing countries through synergies and linkages among various sub-regions [27].

The Organization for Economic Co-operation and Development (OECD)/International Energy Agency (IEA), and recent reports on World Energy Outlook 2004 [28] project that over the next 30 years global primary energy demand will grow by $1.7 \%$ per annum from 9.20 billion tones to 15.30 billion tones of Oil Equivalent, and that this demand will be met primarily by conventional fossil energy such as oil, natural gas and coal, in the near term. Energy from the renewable resources is also expected to grow in the mid century term, but will remain in the small percentages of the total energy mix in near term. Based on a number of statistics it is also projected that many communities across the globe (1.40 billion people according to IEA) living at or below the poverty line will remain without the access to modern energy systems such as electricity, which an essential requirement for social and economic development. The overall value of the global carbon market was estimated at over $\$ 10$ billion in 2005. The World Bank has been a pioneer in the carbon market, mainly through the establishment of carbon procurement funds to secure carbon credits on behalf of investors. The funds in the World Bank portfolio were not solely intended to procure carbon credits, but also to help create demand and spur the global carbon market [29].

\subsection{Addressing Climate Change and Sustainable Development Issues}

Sustainable development has become part of all climate change policy discussions at the global level, particularly due to adoption of Agenda 21 and the various Conventions resulting from the UNCED [30]. The generally accepted and used definition as given by the Brundtland Commission is "development that meets the needs of the present without compromising the ability of future generations to meet their own needs" [31]. Climate change and other sustainable development policies are often but not always synergistic. There is growing evidence that decisions about macroeconomic policy, agricultural policy, multilateral development bank lending, insurance practices, electricity market reform, energy security and 
forest conservation. On the other hand, decisions about improving rural access to modern energy sources for example may not have much influence on global GHG emissions. Climate change policies related to energy efficiency and renewable energy are often economically beneficial, improve energy security and reduce local pollutant emissions. Other energy supply mitigation options can be designed to also achieve sustainable development benefits such as avoided displacement of local populations, job creation, and health benefits.

Sustainable development has become an integrating concept embracing economic, social and environmental issues [32]. Sustainable development does not preclude the use of exhaustible natural resources but requires that any use be appropriately offset. Three critical components in promoting sustainable development are economic growth, social equity and environmental sustainability. Switching to more sustainable development paths can make a major contribution to climate change mitigation, but implementation may require overcoming multiple barriers. There is a growing understanding of the possibilities to choose and implement mitigation options in several sectors to create synergies and avoid conflicts with other aspects of sustainable development. Making development more sustainable by changing development paths can make a major contribution to climate change mitigation, but implementation may require resources to overcome multiplebarriers. There is a growing understanding of the possibilities to choose and implement mitigation policies in several sectors to realize synergies and avoid conflicts with other dimensions of sustainable development. Climate change is already a major driver of impoverishment and conflict around the world, but that fact has not yet been given the urgent attention it demands.

\subsection{Sustainable Energy Development for Asia-Pacific Region}

The Asia-Pacific region, among the world's most populous and diverse, includes many of the world's communities that are most at risk from catastrophic events brought about by climate change and other fossil-fuel consumption related impacts. The region needs a coherent and effective framework for sustainable developmentwhich inevitably has to mandate the rapid deployment of renewable energy and energy efficiency policies and practices. Along with growth, Asia's energy consumption has been rising steadily, and the need to reduce poverty and meet the Millennium Development Goals means that it will continue to rise. With most of its energy coming from fossil fuels-a primary source of greenhouse gas emissions or GHGs-Asia now accounts for nearly one- quarter of the world's GHG emissions.
The International Energy Agency [27] has estimated that the region will require between $\$ 4$ trillion and $\$ 5$ trillion from now to 2030 for new energy infrastructure. Most of these investments will be directed toward electricity, primarily coal-fired power plants. On this basis, it is reported that the global energy-related carbon dioxide emissions will surpass 40 billion tones in 2030, with Asia contributing about $40 \%$ of total emissions.

The World Summit on Sustainable Development (WSSD) took place from 26 August - 4 September 2002, in Johannesburg, South Africa. The goal of WSSD was to hold a 10-year review of the 1992 United Nations Conference on Environment and Development (UNCED) to reinvigorate global commitment to sustainable development [33]. The WSSD brought together more than 20,000 formally registered participants from 191 governments, 118 United Nations agencies and international organizations, numerous non-governmental organizations, as well as representatives from the private sector, civil society, academe and the scientific community. In the context of Sustainable Development in the Asia and Pacific region, the chapter on regional initiatives calls for action in the following areas: capacity building for sustainable development; poverty reduction; cleaner production and sustainable energy; land management and biodiversity conservation; protection and management of and access to freshwater resources; oceans, coastal and marine resources and sustainable development of small island developing states; and atmosphere and climate change.

The World Council for Renewable Energy (WCRE) [34] called for the urgent development and enactment of such a framework. It is ready to assist governments and intergovernmental organizations in the energy policy formulation process as well as in the adoption of specific sustainable energy strategies. Such strategies are to reinforce existing sustainable development efforts, pursued in the region by national, provincial and municipal governments, a number of aid and lending institutions and a large number of non-governmental organizations. Most present development programs are still far too reliant on fossil-fuel or nuclear-based projects. Furthermore, regional development policy signals set by many leading countries are frequently coloured by short-term resource extraction and trade objectives with too little regard for local and global sustainability. The local viability of the poorest nations and indigenous communities remains severely under-recognized. The WCRE Asia Pacific urges the implementation of the recommendations of the World Bank Extractive Industries Review final report "Striking a Better Balance" as they relate to renewable energy, specifically to the following: 1) assist governments to adopt sustainable energy strategies that address the en- 
ergy needs of the poor and minimize externalities such as climate change; 2) internalize the cost of greenhouse gas emissions into all World Bank Group (WBG) economic decision-making; 3) increase investments in sustainable energy resource development. This includes setting targets for increasing proportions of investment in renewable energy within the energy portfolio, increasing annually at 20 per cent to achieve a better balance with support for other projects; 4) phase out lending in fossil fuel projects over time and 5) implement initiatives for technology transfer related to climate change and further research into appropriate technology.

\section{Conclusions}

For a rapid economic development, both the developed as well as the developing economy of the world are using energy-intensive technologies, making extensive use of fossil-fuels as feedstock. Over the years, this has caused a huge build-up of Green House Gases (GHGs) causing adverse impact on the environmental quality, human and animal lives. Several other anthropogenic activities are also the potent sources of pollution. In the process, the emissions level is also rising phenomenally along with the phenomena of Global warming; and this is also becoming quite alarming, affecting the environmental quality as also its security concerns globally. This paper has brought out clearly the major impacts of global warming and consequential climate change on the environmental quality and overall security aspects-including commercial, strategic and defense related security aspects for the South-Asian region. The paper has also spelt out in some length the future strategy linked to the question of energy security as well as the environmental security through the pathways of sustainable energy development for achieving a balanced economic development for the South Asian region. The significance of International cooperation in the mitigation and adaptation actions to offset emerging climate change impacts, with special reference to Asia-Pacific and South Asian region, has also been discussed in the paper. In sum, while there is an imperative for the South Asian Countries to accelerate their process of economic growth for the region's economic prosperity in a globally competitive manner, there is also a need to focus on energy and environmental security aspects of the region for a balanced and sustainable development.

\section{REFERENCES}

[1] A. Shah, "Climate Change and Global Warming; Social, Political, Economic and Environmental Issues That Affect Us All,” Accessed on 25 December 2004. http://www.globalissues.org/issue/178/climate-change-an d-global-warming
[2] Intergovernmental Panel on Climate Change (IPCC), "Climate Change, Third Assessment Report (Volume I)," Cambridge University Press, Cambridge, 2001

[3] Greenhouse Effect http://en.wikipedia.org/wiki/Greenhouse_effect

[4] Green House Effect-The Background Material. http://www.ucar.edu/learn/1_3_1.htm

[5] J. A. Church, P. L. Woodworth, T. Aarup and W. S. Wilson, "Understanding Sea-level Rise and Variability," Wiley-Blackwell, London, 2010, 428 Pages.

[6] C. K. Folland and T. R. Karl, "Observed Climate Variability and Change, In: Climate Change 2001, The Scientific Basis, Cambridge University Press, New York, 2001.

[7] J. Hansen, et al., "Earth’s Energy Imbalance: Confirmation and Implications,” Science, Vol. 308, 2005, p. 1431.

[8] A. Shah, "Climate Change \& Global warming: Glo Cli Ch-Res Art," Climate Change and Global WarmingGlobal Issues, 2008.

[9] I. Douglas, "Climate Change, Flooding and Food Security in South Asia, Food Security,” Springer, Netherlands, 2009.

[10] Union of Concerned Scientists: Citizens and Scientists for Environmental Solutions, Solutions to Global Warming in Asia: Early warning signs.

http://www.climatehotmap.org/global-warming-solutions/ asia.html

[11] J. Mehovic and J. Blum, "Global Warming and Melting Glaciers in South Asia: Environmental, Economic, and Political Implications,” SARID, 17 September 2004. http://www.sarid.net/sarid-archives/04/040917-mehovicblum.htm

[12] R. Francisco, “Main Points from ADB's Report on the Economics of Climate Change in Southeast Asia, Manila, Reuters,” 26 April 2009.

[13] A. Najam, "The environmental challenge to human security in South Asia,” In: R. Thakur and O. Wiggen, Eds., South Asia in the World: Problem solving perspectives on Security, Sustainable Development and Good Governance, United Nations University Press, New York, 2003

[14] S. Burgess, "India's Emerging Security Strategy and Defense Capabilities," The Annual Meeting of the American Political Science Association, Boston Marriott Copley Place, Sheraton Boston \& Hynes Convention Center, Boston, Massachusetts, 28 August 2002, Accessed on 7 December 2009. http://www.allacademic.com/meta/p66557_index.html

[15] Climate Change and its Impact of India, http://www.greenpeace.org/india/Campaigns/choose-posi tive-energy/what-is-climate-change...

[16] National Security and the Threat of Climate Change: Military Advisory Board Findings, Military Advisory Board, Wikipedia: http://en.wikipedia.org/wiki/Military_Advisory_Board) http://www.pewclimate.org/mabsummary.cfm

[17] A. France-Presse, “The New York Times reported on 'Climate change that will pose profound strategic chal- 
lenges to the United States in coming decades,, Washington DC, 8 August 2009.

[18] J. Lobe, "Global Warming Is Biggest Security Threat," Washington DC, 5 November 2007 (IPS). http://ipsnews.net/news.asp?idnews=39927

[19] Environment and Security Policy; IISD. http://www.iisd.org/security/es/policy/

[20] R. Piltz and A. Jay, “Climate Science Watch,” 29 September 2009.

http://www.climatesciencewatch.org/index.php/csw/detail s/climate-security-index/

[21] Earth Summit: from Rio to Johannesburg, Rio Earth Summit in 1992, Friends of the Earth 26-28 Underwood Street, London N1 7JQ. http://www.foe.co.uk/resource/briefings/earth_summit.pd $\mathrm{f}$

[22] D. Pearce and G. Atkinson, "The Concept of Sustainable Development: An Evaluation of Its Usefulness Ten YEARS after Brundtland,” CSERGE Working Paper PA 98-02.

http://www.uea.ac.uk/env/cserge/pub/wp/pa/pa_1998_02. htm

[23] A. Garg, D. Ghosh and P. R. Shukla, "Energy Sector Policies and Mitigation of GHG Emissions from India," In: M. Toman, Ed., Climate Change Economics and Policy: Indian Perspectives, Resources for the Future Publication, Washington DC, 2003.

[24] W. Chandler, R. Schaffer, Z. Dadi, P. R. Shukla, F. Tudela, O. Davidson and S. Alpan-Atamar, "Climate Change Mitigation in Developing Countries," Report, The Pew Center on Global Climate Change, Washington DC, Bhagirath Jogdand, October 2002. http://international-environmental-affairs.suite101.com/ar ticle.cfm/climate_change_impact_on_food_security

[25] Bhagirath Jogdand, http://international-environmental-affairs.suite101.com/ar ticle.cfm/climate_change_impact_on_food_security
[26] Trans-Asian Energy Systems, “A UNESCAP Initiative: Trans-Asian Energy Cooperation Initiatives of ESCAP,” http://www.unescap.org/esd/Energy-Security-and-WaterRe-

sources/energy/trade_and_cooperation/transasian/docume nts/TAES_profile.pdf.

[27] IEA, "World Energy Investment Outlook: 2003 Insights, OECD/IEA,” Paris, 2004.

[28] C. Feinstein, "Economic Development, Climate Change \& Energy Security: The World Bank’s Strategic Perspective,” Energy \& Mining Sector, Board Discussion Paper Series; Paper No. 3, September 2002.

[29] World Bank, "State and the Trends of Carbon Market," World Bank Institute/International Emissions Trading Association, Washington DC, 2007.

[30] UNCED-1992, United Nations Development Agenda for All Goals, Commitments and Strategies Agreed at the United Nations World Conferences and Summits since 1990, Department of Economic and Social Affairs, United Nations, New York, 2007. http://www.un.org/geninfo/bp/enviro.html

[31] Brundtland Commission Report, "Report of the World Commission on Environment and Development,” 1987. http://simple.wikipedia.org/wiki/Brundtland_Commission \#cite_note-0

[32] S. M. L'el'e, "Sustainable Development: A Critical Review," World Development, Vol. 19, No. 6, 1991, pp. 606-607. doi:10.1016/0305-750X(91)90197-P

[33] World Summit on Sustainable Development (WSSD), "Development Imperatives," 2002. http://www.gdrc.org/uem/energy/renewable-energy-agen da-2004.html

[34] World Council for Renewable Energy (WCRE-World Bank), 2004. http://www.gdrc.org/uem/energy/renewable-energy-agen da-2004.html 